Historic, archived document

Do not assume content reflects current scientific knowledge, policies, or practices. 



\section{A DESCRIPTIVE CATALOGUE OF THE SOILS OF VIRGINIA SO FAR IDENTIFIED IN THE SOIL SURVEY.}

\section{AREAS SURVEYED. ${ }^{1}$}

The Bureau of Soils has surveyed 12 widely separated areas in Virginia, covering parts or all of 31 counties and aggregating $4,138,022$ acres, or about one-sixth of the State. For purposes of soil classification the State has been divided into five soil provinces, the areas of which are approximately as follows:

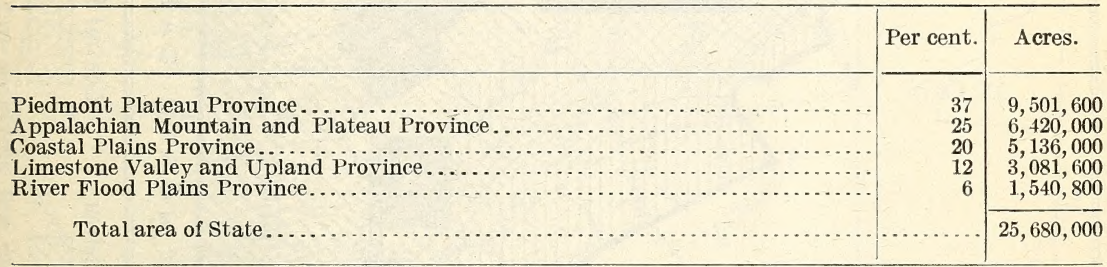

1 Explanation of TERMS.-For purposes of soil classification the United States east of the Great Plains region has been divided into seven great soil provinces, based upon the mode of origin of the soil material. In the Piedmont Plateau Province the soils have been derived directly from the disintegration of the old crystalline and metamorphic rocks in place. In the River Flood Plains Province the soils are composed of material, more or less mixed, which has been carried by the rivers, particularly in flood, and deposited on more or less well defined terraces. In the Coastal Plains Province the material thus carried by the rivers has been subjected to wave and current action of the ocean, with considerable separation and segregation of material, based upon the size of grain and depth and movement of the ocean water. The Appalachian Mountain and Plateau Province is in effect an old coastal plain, when the material, after segregation into sand beds and clay beds, with the deposition of lime in places, has subsequently been consolidated into sandstone shale and limestone rocks and greatly elevated above present sea level. The present soils are derived from the disintegration of these secondary rocks in place. In the Limestone Valley and Upland Province the soils are derived from the solution of the lime carbonate, leaving the impurities of the old limestone rocks as present soil material. In the Glacial and Loessial Province the soils have resulted from the grinding and transportation of rocks and unconsolidated material by ice and from deposits formed by wind and rushing glacial waters. In the Glacial Lake and River Terrace Province the soils are derived from glacial material reworked and sorted out by wave and current action of the old glacial lakes and rivers, which have now largely disappeared.

The names given to soil types, such as Norfolk sandy loam or Portsmouth sandy loam, are usually names of towns in the areas where the types are first encountered and are used for purposes of identification and as being more distinctive and easier to remember than numbers. They have no further significance. All types having the same name, such as the Norfolk sand, Norfolk fine sand, and Norfolk sandy loam, together constitute a soil series.

$$
14272^{\circ}-\text { Bull. } 46-13-1
$$




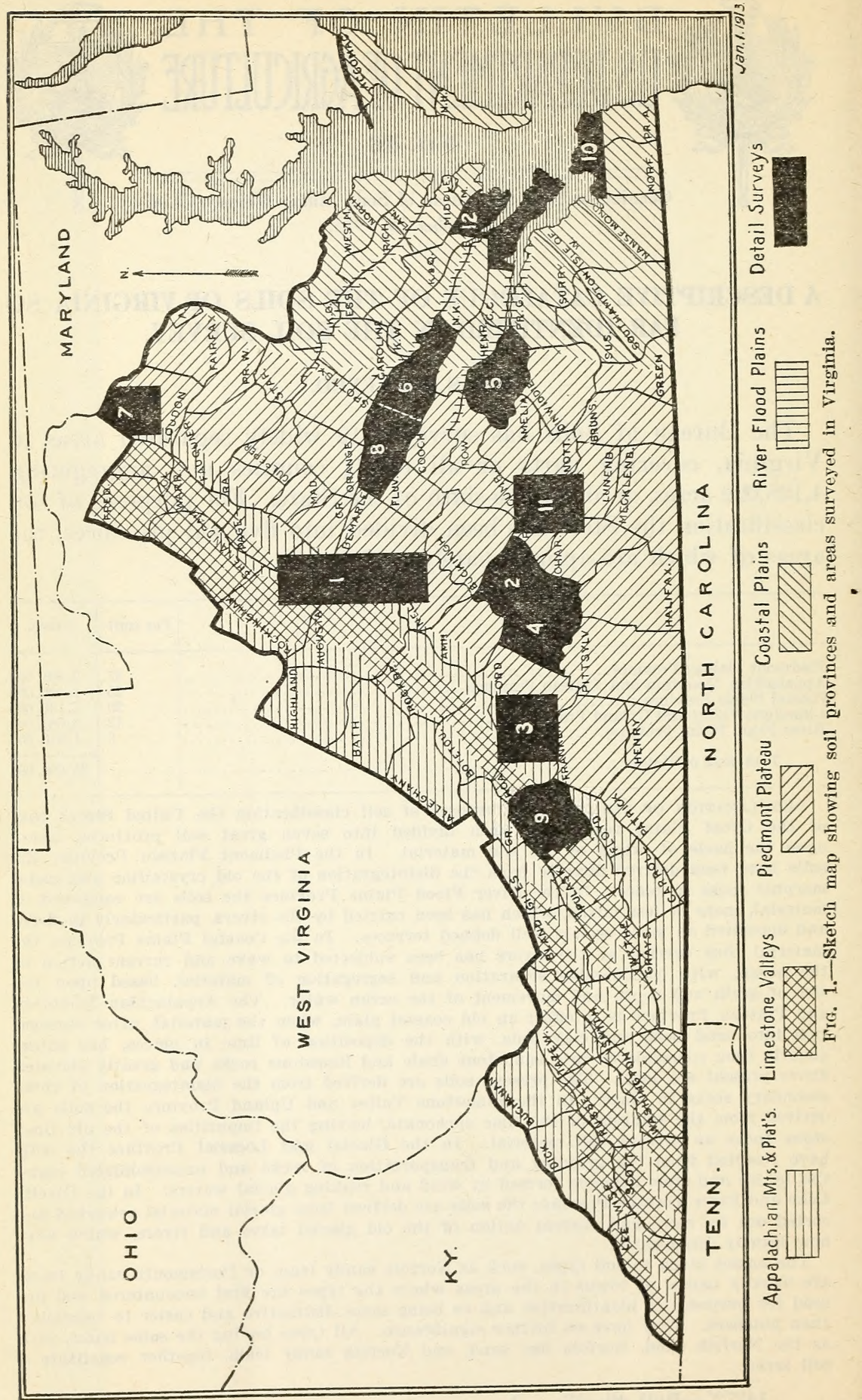




\section{DESCRIPTION AND USE OF THE SOILS OF THE PIEDMONT PLATEAU PROVINCE.}

Cecil series.-The Cecil series includes the most important and widely distributed soils of the Piedmont Plateau. The heavier members are known as the "red-clay lands." These soils are characterized by their red-clay subsoils and gray to red soils, ranging in texture from sand to clay, the lighter colors prevailing in the sandy members. A characteristic of the subsoil is the content of sharp quartz sand and the frequent occurrence of veins of quartz. Mica flakes are also usually present in the subsoil. The soils are of residual origin and derived principally from granite and gneiss, weathered to great depths, so that rock outcrops are rare. Fragments and bowlders of the parent rock are, however, found in places on the surface. The topography is rolling to hilly, with level to undulating areas in

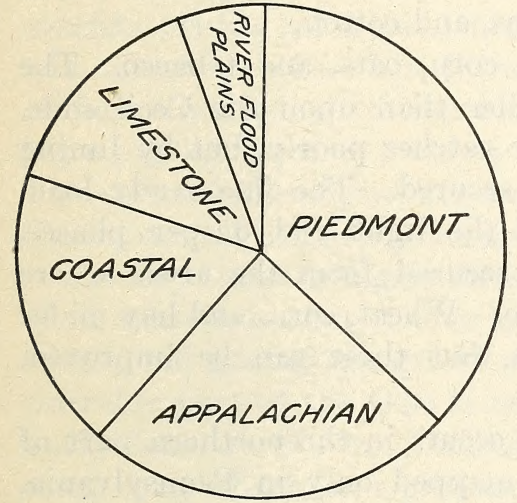

FIG. 2,-Relative area of soil provinces.

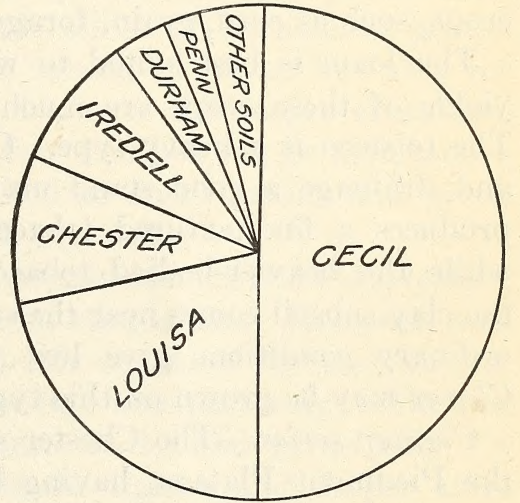

FIG. 3.-Relative area of Piedmont soils.

situations where stream erosion has not been too active. The soils of the Cecil series are adapted to the general farm crops.

The sandy loam is best suited to the lightest type of general farming, with light teams, tools, and farm buildings. It is an important corn soil and is fairly well adapted to wheat, oats, clover, grasses, and cowpeas. This type ranks with the Durham sandy loam as one of the two most important tobacco soils in the Danville region. It is used for bright cigarette and smoking tobacco where the red-clay subsoil is 8 inches or more below the surface and for manufacturing types of tobacco where it is nearer the surface. It is adapted to sweet and Irish potatoes, tomatoes, rye, berries, and garden vegetables, but requires considerable organic matter and intelligent rotation of crops to attain its best development. The clay is adapted to and can only be maintained at its highest efficiency by the heaviest types of general farming, with heavy teams and tools and commodious buildings for the storage of bulky and heavy products. This type of farm- 
ing is represented by intensive dairying, where the cattle are kept inclosed most of the time and fed. It is a fine grain soil, but is better for red clover, orchard grass, and other hay grasses than for pasture grasses. It is also well adapted to cowpeas and to fall and winter apples of the general class of the Winesap, and produces a heavy leaf tobacco for plug fillers and for the export trade.

Louisa series.-The soils of this series are gray to light gray and the subsoils red. The material is derived from talcose and micaceous schists and imperfectly crystalline slates. The structure is unfavorable to the maintenance of good tilth, and the soils have a tendency to bake and check on drying. The members of this series are less productive than the corresponding types of the Cecil series. They can, however, be improved, especially by fall plowing, the growing of legumes and winter cover crops, liming, and the incorporation of organic matter. They are best suited to general farm crops, such as corn, grain, forage crops, and cotton.

The loam is best suited to wheat, corn, oats, and tobacco. The yields of these crops are much smaller than upon the Cecil soils. The tobacco is a heavy type. Clover catches poorly, but by liming and drainage a good stand may be secured. The fine sandy loam produces a fine-textured tobacco on the light and deeper phases, while the heavier-bodied tobacco is secured from the areas where the clay subsoil comes near the surface. Wheat, corn, and hay under ordinary conditions give low yields, but these can be improved. Clover may be grown on this type.

Chester series.-The Chester series occurs in the northern part of the Piedmont Plateau, having been mapped only in Pennsylvania, Maryland, and Virginia. The types in this series differ from those of the Cecil series in having yellow or only slightly reddish-yellow subsoils and gray or brown surface soils, the latter being, on the whole, lighter and more friable than the Cecil. The members of this series are prevailingly more micaceous than the Cecil soils. Locally they are known as "gray lands" to distinguish them from the "red lands" of the Cecil series. The topography in general is not so rough as over Cecil areas, being rolling to moderately hilly. The soils, which are of residual origin, are derived from igneous and metamorphic rocks, principally gneiss, schist, and granite. Weathering has not reached to such great depths as in the case of the Cecil series, the underlying rock often being encountered within 2 feet of the surface on eroded slopes. The soils are adapted to general farm crops, especially corn, and also to fruit and canning crops. Of the latter, tomatoes and sugar corn are the most important.

The loam is well suited to corn, oats, wheat, grass, clover, apples, and pears. It is one of the best corn soils in the Leesburg section. Grass and clover yield well and furnish good grazing during a con- 
siderable part of the year. In some sections apples and pears, usually in small orchards, are grown successfully. Bluegrass makes a lasting pasture and dairying is one of the features of agriculture on this type. This soil is well adapted to canning crops, especially tomatoes and sweet corn.

The sandy loam occupies a comparatively small area. It is best adapted to corn, vegetables, and small fruits. Good yields of corn are secured, and occasionally wheat gives good returns, especially on the heavier phase of the type. Grass and clover do fairly well.

Iredell series.-The soils of the Iredell series vary from lightbrown to almost black in color and frequently carry small iron concretions. The subsoils consist of extremely plastic, sticky, or waxy clay of a yellowish-brown to greenish-yellow color. Disintegrated rock is very often encountered within the 3 -foot section. The topography varies from nearly flat to gently rolling. The parent rock consists mainly of diorite, hornblende schist or hornblende gneiss, and chloritic rocks. The intractable subsoil in places lies near the surface, making cultivation difficult, but over the deeper areas having a soil lighter than a clay a very fair seed bed can be maintained. The soils of this series are best suited to small grains and grass. Under certain conditions corn does fairly well.

The clay loam, owing to the impervious character and close texture of its subsoil, is restricted as to its crop adaptation. However, corn wheat, and grasses are grown with a fair degree of success. A considerable part of the type is used for hay and pasturage. The fine sandy loam is of very limited extent. It is used principally for corn, oats, wheat, and grasses, while the lighter and deeper areas are used to some extent for the production of tobacco. The sandy loam, the only type so far mapped in the State, is one of the important soils of the Piedmont Plateau. It is admirably adapted to the production of bright tobacco, but is usually too light for the profitable growing of grasses and small grains. It is used advantageously for the production of corn, sweet potatoes, melons, garden vegetables, and fruits.

Penn series.-The Penn series includes Indian-red soils derived from red sandstone and shales of Triassic age. Detached areas of these rocks occur in shallow basins in the Piedmont Plateau from the vicinity of New York City to South Carolina. In productiveness and crop adaptation the Penn series may be considered as intermediate between the Hagerstown and Cecil soils. Corn, wheat, oats, potatoes, grass, apples, and peaches are produced on different types of the series in Virginia and the more northern States and tobacco in Virginia.

The clay, although occupying small areas, is an important soil in restricted sections of the State. It is well suited to the production 
of corn, wheat, clover, and grasses. Of these crops corn, clover, and grasses give the best returns. Apples do well on this soil and there are many small orchards on it. It is a soil which has to be handled with considerable care. The loam is used for the production of corn, wheat, grass, clover, apples, and small fruits. Grazing, stock raising, and dairying are practiced on a small scale. With judicious management good yields of corn, wheat, and grasses can be secured. The sandy loam is a small and unimportant agricultural soil. The greater part of it is in forest. This soil was formerly used for wheat and tobacco, but now corn and wheat are the principal crops grown.

The Penn stony loam is of very limited extent and of little agricultural importance. When the stones are removed corn, wheat, and a few apples and small fruits are grown. The gravelly loam has a very small representation in the State. It will produce corn and wheat, but cultivation is difficult where the gravel is plentiful.

York series.-The types included in the York series are gray to light gray at the surface and have yellow subsoils. They are derived from talcose and micaceous schists and imperfectly crystalline slates. The texture and structure of the soil are unfavorable to the maintenance of good tilth, as the surface bakes and checks readily, making cultivation difficult. Crop yields are generally low, and the soils are exceedingly difficult to improve.

The York fine sandy loam is considered a thin soil, and small yields of tobacco, corn, wheat, and oats are secured. This soil is slightly less productive than the Louisa fine sandy loam. Heavy fertilization is necessary to produce profitable crops. The York loam is held in low esteem as an agricultural soil and practically none of it is under cultivation.

Worsham series.-The soils of the Worsham series are composed of light-gray surface soils and yellowish or mottled yellow, gre and red plastic clay subsoils. They occur throughout the Piedr or. region in comparatively small areas, in which, owing to the imperviousness of the subsoils, the drainage is poorly established. The parent rocks consist principally of granite, gneiss, and associated formations. The agricultural value of these soils is low and they should be left in forest.

The sandy loam, the only type so far mapped in the State, is of very small extent. This soil is suited to the production of orchard grass, herd's-grass, and timothy. On some small areas a heavy shipping tobaco is grown.

Conowingo series.-The Conowingo series is characterized by the grayish-yellow to brownish color of the soils and the yellowish color of the subsoils. Some areas mapped have a red subsoil and represent 
possibly soils that should be separated from those having a yellow subsoil. The Conowingo soils are derived from talcose material having a decidedly greasy subsoil and are locally known as "soapstone lands." The topography is rolling to hilly, although there are occasionally poorly drained flat areas which are locally known as "glades."

A considerable proportion of the clay member, the only type so far mapped in this series, is fairly well suited to the production of general farm crops, but is better left in forest. The "barrens" phase, which in places is very stony, and the topography of which is hilly to broken, is generally quite unproductive and probably worthless for agricultural purposes.

Lansdale series.-The Lansdale series is characterized by the gray, drab, or brownish color of the soils and the gray, slaty to paleyellowish color of the subsoils. These soils occur in close association with the Penn series, and are derived from metamorphosed Triassic sandstone and shale, prevailingly of a grayish color. The metamorphism has resulted chiefly from the heat of the intrusive rocks with which the typical Lansdale areas are associated. The topography ranges from rolling to hilly and the drainage is good. The agricultural value of these soils is somewhat lower than that of the corresponding members of the Penn series. Moderate yields of corn, oats, wheat, Irish potatoes, and hay are secured.

The silt loam, the only type so far mapped in the State, is only fairly productive. It is best suited to corn, wheat, clover, timothy, small fruits, and vegetables. It is better adapted to wheat than to corn.

Manor series.-The Manor soils are characterized by their yellowish-brown to brown surface color and the yellow to yellowish-red or dull-red color of the subsoils. Both soil and subsoil have a high content of mica, which gives a greasy feel, particularly to the subsoil material. The soils of this series are derived from phyllites, including mica schist and chlorite schist. Fragments of these rocks are of common occurrence throughout the soil section, some areas being very stony. The members of this series are confined to the Northern Piedmont, where they occupy gently rolling to hilly areas. When properly handled the better-lying areas give good yields of oats, corn, wheat, Irish potatoes, and hay. These soils are locally known as "slate lands," "dark slate lands," and "white slate lands," the last two designations originating from local variations in the color of the surface soils.

The only type of the Manor series so far encountered in Virginia is a small area of the loam, which is of minor importance and should be used for forestry, chestnut orchards, and grapes. 


\section{DESCRIPTION AND USE OF, THE SOILS OF THE APPALACHIAN MOUNTAIN AND PLATEAU PROVINCE.}

Dekalb series.-The surface soils of the Dekalb series are gray to brown, while the subsoils are yellow. The soils are derived from the disintegration of sandstone and shales, from Silurian to Carboniferous in age. The surface features consist of gently rolling tablelands, hills, and mountains. These soils are generally not very productive. The stony and sandy members of the series are adapted to orchard fruits, while the heavier soils make good hay and pasture land.

The stony loam covers about one-half of the total area included in this series. The rough and broken character of the surface and the large quantity of stones render this soil a typical forest type, unsuited for agricultural purposes. It is only upon the more level places after the stones have been removed that corn and wheat can

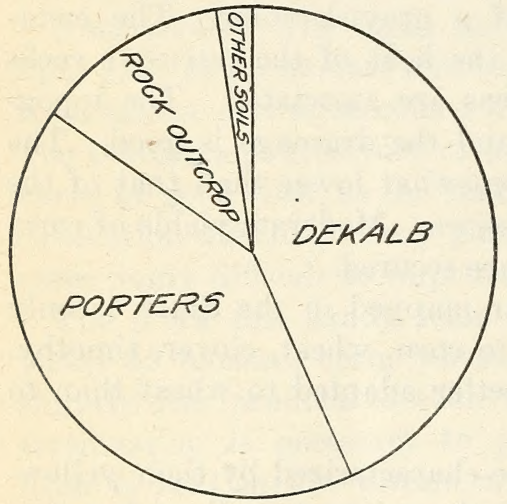

Frg. 4.-Relative area of Appalachian soils. be grown, but the yields are too small for profitable farming. Apples and peaches may be grown in local areas. Much of the type should always be in forest or used for grazing and range. The shale loam ranks next in extent to the stony loam. It is also a forest type. When cultivated it is best adapted to wheat and grass or those crops which can be harvested before dry weather comes or which can withstand the drought. Occasionally fair yields of corn can be secured. The silt loam has a com-

paratively small representation in the series. The lower-lying areas are best suited to the growing of corn, wheat, and timothy. Much of the type is too hilly and broken for cultivation, but can be used for forestry and pasturage, as it supports a fairly good growth of native grasses. The fine sandy loam occupies a small area and has a low agricultural value. Small yields of wheat and corn are secured. Small fruits and vegetables are best suited to this soil.

Porters series.-The Porters series includes the residual soils of the Appalachian Mountains derived from igneous and metamorphic rocks. The soils are analogous to those of the Cecil series, but are classed separately, on account of the difference in topographic position. They occur at high elevations and are therefore influenced more or less by different climatic and drainage conditions. The mountainous character of the country in which the Porters soils are found renders them difficult of cultivation, and they are generally 
best adapted to forestry. On the more level and less elerated areas wheat, corn, rye, barley, and fruits, especially apples, are produced. The soils are particularly adapted to fruit culture, and this industry is rapidly extending. At a medium elevation and under suitable conditions of slope and exposure fruit is the principal crop. Cattle raising is one of the most important industries.

The sand, which occupies a large area, possesses a high agricultural value aside from forestry. It is best adapted to the production of peaches, grapes, berries, and to light farming, including garden vegetables. The black loam is a productive soil, but its isolated situation and steep surface do not admit of extensive cultivation. It is especially adapted to apples, the Albemarle pippin in particular, which finds its best development in the cores on the east side of the mountains. The clay is best adapted, aside from forestry, to wheat, corn, clover, and timothy. Bluegrass and timothy make a good pasture. This type is one of the most important apple soils of the mountains, particularly for the Winesap and similar varieties. Much of the type is too rough and steep for farming purposes and must be used for forestry and grazing. The sandy loam is the best generalpurpose soil in the Porters series. It is well adapted to corn, Irish potatoes, rye, apples, peaches, berries, and garden vegetables. Wheat, oats, and clover are suitable crops for the heavier phases of the type.

Talladega series.-The soils of the Talladega series are grayish brown to light brown. The subsoils are red and have a greasy feel. The series is typically developed in the southern Appalachian Mountains, generally occupying strongly rolling to mountainous country. The soils are derived from metamorphic rocks, principally micaceous schists. Large areas of the Talladega soils are best suited to forestry and pasturage. The smoother areas give moderate results with corn, forage crops, and in the South with cotton. The soils are probably stronger than those of the Chandler series, from which they differ physically chiefly in the red color of their subsoils.

The loam occupies a small area and is best suited to corn and wheat, although fair yields of oats and grasses may be obtained. The gravelly loam is of very small extent. It is too gravelly in some places to be cultivated and possesses no special adaptations.

Upshur series.-In the Upshur series both soils and subsoils are Indian red. Some types have a grayish to grayish-red color in the surface soils. These soils are closely associated in occurrence with the Dekalb. They are derived from Indian-red sandstone and shales, frequently of a calcareous nature. They occupy strongly rolling to mountainous country, and drainage is well established. The soils of this series are generally more productive than the corresponding members of the Dekalb series. The silt loam is the only type which $1427 \check{2}^{\circ}-$ Bull. $46-13-2$ 
has been encountered in the State, and this only to a rery small extent.

Paris series.-The soils of the Paris series are dark gray to dark brown and are usually rich in organic matter. The clay subsoils are brownish to reddish brown. Drainage is well established. These soils are dereloped on nearly flat table-land areas in cores. They are well suited to general farm crops, such as corn and grain. The loam is the only type which has been encountered in the State, and this only to a very small extent.

Chandler series.-The Chandler series consists of gravish-brown to light-brown soils and yellow to reddish-rellow subsoils, the latter haring a greasy feel. The types of this series are dereloped typically in the southern Appalachian Mountains and hare been encountered to only a small extent in Virginia. They are derived from metamorphic rocks, chiefly micaceous schists. Large areas of the series are rough in topography and stony. These soils are best suited to pasturage and forestry. They are similar in many respects to the Talladega soils, differing principally in the yellor color of their subsoils.

The loam is the only type that has been mapped. and this is of no importance for agriculture.

\section{DESCRIPTION AND USE OF THE SOILS OF THE COASTAL PLAINS PROVINCE.}

Norfoiti series.-The Norfolk soils are characterized by the lightgray to grayish-yellow color of the surface soils and the yellow color and friable structure of the subsoils. They occupy nearly level to rolling uplands throughout the Atlantic and Gulf Coastal Plains, and hare been derired mainly from Piedmont-Appalachian material. The sandy members predominate. These soils are usually deficient in organic matter, which should be added in liberal quantities in an intensire srstem of agriculture in order to maintain them in their best condition. The members of this series are variously adapted to early, medium, and late truck crops, and, together with the Portsmouth series, constitute the great truck soils of the coast country. It is estimated that on about 30.000 acres, or considerably less than 2 per cent of the Norfolk series. there are produced. under intensive methods, early truck crops to the ralue of $\$ 10.000 .000$ : on about 3 per cent. sweet and Irish potatoes to the ralue of $\$ 8.500 .000$ : and on 5 per cent, prinsipally in ten of the southeast counties of the State, peanuts to the ralue of $\$ 4.500 .000$. The remaining 90 per cent of the area of these soils is lying idle or is used for general farming. to which they are not adapted.

Tnder similar conditions of climate and exposure the sand is the earliest soil in maturing crops of light yield and is used particularly 
for extra-early asparagus, Irish potatoes, peas, beans, tomatoes, egg plant, melons, cantaloupes, and small fruits. The fine sand is better adapted to these crops, giving larger yields, but the crops mature from ten days to two weeks later. This is the main truck soil of the Norfolk district. The sandy loam and the fine sandy loam are best adapted to sweet and Irish potatoes, early sweet corn, melons, the heavier truck crops, like kale, spinach, and cabbage, and to peanuts. The fine sandy loam gives better yields than the sandy loam. The silt loam, which occurs to a small extent, is the only soil of the Norfolk series found in the State which is well adapted to general farm crops, such as corn, wheat, and oats. The remaining types, coarse sandy loam, gravelly loam, and clay loam, are of comparatively rare occurrence and have no particular value.

Portsmouth series.-The soils are dark gray to black and are high in organic matter. The subsoils are light gray to mottled gray and yellow, and the heavier members are always plastic, though usually carrying a noticeable percentage of sand. These soils are most extensively developed in the flatwoods or the low seaward portion of the Atlantic Coastal Plains and that portion of the Gulf Coastal Plains lying east of the Mississippi River. They are poorly drained and require ditching before they can be used for agriculture. Scattered areas are frequently found in the poorly drained depressions of the higher Coastal

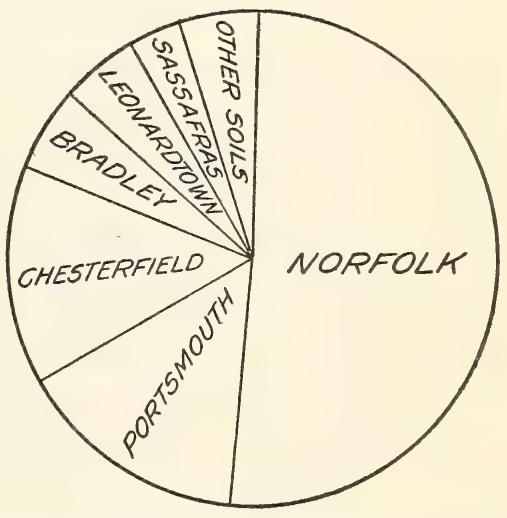

FIG. 5.-Relative area of Coastal Plains soils.

Plains country. When drained these soils are variously adapted to corn, strawberries, and truck crops, such as cabbage, onions, and celery. Applications of lime are usually decidedly beneficial.

The silt loam is one of the extensive and important types in the series. It is devoted principally to general farming, including corn, hay, and oats. It is also well suited to the production of cabbage, kale, collards, and certain varieties of strawberries. The sandy loam and fine sandy loam are the important truck soils of the series and are well adapted to late and heavy truck crops, especially cabbage, kale, spinach, celery, onions, lettuce, and strawberries. Larger yields are secured from these soils than from the corresponding types of the Norfolk series. The fine sandy loam is probably the best strawberry soil of the Coastal Plains. The clay loam occupies only small spots. It is a splendid soil for corn, oats, and grasses, and good pasture can 
be maintained. The sand has not been drained and reclaimed to any extent for agricultural purposes.

Chesterfield series.-The soils are generally gray in color, with friable yellow subsoils. The series represents soils having a thin layer of Coastal Plains material (Norfolk) overlying residual Piedmont material (mainly Durham). The members are developed near the junction of the Coastal Plain and Piedmont, or where there is an overlapping of sedimentary upon residual material. They are adapted to the general farm crops of the region, principally corn, oats, forage crops, and cotton.

The sandy loam occupies a fairly large area along the borders of the Coastal and Piedmont boundary, and is used principally for the production of corn, wheat, oats, and tobacco. It is also adapted to truck crops, peaches, and small fruits for local markets. The gravelly sandy loam is used to a rery limited extent for farming purposes. It should be devoted to pasture and orchard fruits.

Bradley series.-The surface soils are grayish and sandy. The subsoils are predominantly red, in places slightly mottled with yellow or gray, of clay texture. The series represents soils having a thin surface mantle of Coastal Plains material (Norfolk) and residual Piedmont material (mainly Cecil). These soils are developed most extensively near the junction of the Coastal Plains and Piedmont, or in that region where there is an overlapping of sedimentary material made up of reworked Piedmont-Appalachian upon residual Piedmont material. They are adapted to the general farm crops of that region, principally corn, oats, forage crops, and, in the southern part of the State, cotton. Only the sandy loam has been encountered so far in the State, and this is not so productive as the Cecil sandy loam.

Leonardtown series.-The soils of this series are gray to paleyellow in color. The subsoils are mottled gray, yellow, and red and ordinarily carry clay lenses and pockets of sand. These soils occupy gently rolling to rolling country in the Chesapeake Bay region of the Coastal Plains, where the Glacial-Piedmont-Appalachian material has been deposited. They are best suited to the general farm crops.

The loam, which is the only type so far encountered in the State, has only in a few instances been handled to show its capabilities. The poor natural drainage of this type has retarded its development. When properly prepared it is suited for pasturage, corn, grass, and late truck.

Sassafras series.-These soils are distinguished by their yellowishbrown to brown color and mellow structure. The subsoils are reddish-yellow and friable in structure, resting upon coarser material or beds of gravel and sand at depths varying from $2 \frac{1}{2}$ to 5 feet. The series is of sedimentary origin, the material from which it has been 
derived containing some sediments transported from the area of glaciation and added to deposits of Piedmont-Appalachian origin. This series is developed along flat marine or estuarine terraces standing from 10 to about 250 feet above sea level. The substratum of gravel makes drainage good. These soils are confined to the northern part of the Atlantic Coastal Plains and include some of the most productive soils of the Atlantic seaboard. Under good management excellent crops of wheat, corn, clover, potatoes, melons, berries, and a number of vegetables are secured. They are particularly adapted to canning crops.

The sandy loam is the only type of the series which has been encountered in the State, and this only to a small extent.

Elkton series.-The soils are light gray to white and the subsoils are mottled whitish gray and yellow. Gravel or coarse sand, usually saturated with water, is found at a depth of $2 \frac{1}{2}$ to 3 feet. These soils are closely associated with the Sassafras, the difference being caused by the intermittent wetting and drying to which the Elkton soils have been subjected, rendering them much lighter in color and lower in agricultural value. They are encountered in that part of the Coastal Plains which has been supplied with Glacial-Piedmont-Appalachian material.

The fine sandy loam, owing to its poor drainage conditions, has not been developed to any extent. Under good drainage ordinary yields of general farm crops can be secured, but the soil is not as productive as the Sassafras sandy loam.

Tidal Marsh varies from dark, oozy sediments, interspersed with coarse marsh-grass roots, to a dark-colored clay. This material is extensively developed along the seacoast and along streams subject to tidal overflow. The vegetation consists of sait grass. Reclamation would be difficult and expensive, as it would require diking and pumping.

Coastal Beach.-This is a light-gray or white, loose, and incoherent sand, 3 feet or more in depth, containing varying quantities of shell fragments. It occurs as beaches, narrow ridges, and islands along the seacoast. It is not adapted to agriculture.

\section{DESCRIPTION AND USE OF THE SOILS OF THE LIMESTONE VALLEY AND UPLAND PROVINCE.}

Hagerstown series.-The soils of the Hagerstown series are prevailingly brown in color, with light-brown to reddish-brown subsoils. In some areas the subsoil is red or dull red, but never so pronounced in color as that of the Decatur series. These soils are most typically developed in the limestone valleys of the Appalachian Mountain region and in the central basins of Kentucky and Tennessee, with outlying areas in the adjoining Piedmont Plateau region. Fragments 
and outcrops of limestone are of common occurrence. The topography is undulating to gently rolling, well suited to cultivation. The soils are very productive and admirably adapted to corn, small grain, clover, bluegrass, timothy, apples, and in the Southern States to cotton.

The stony loam, owing to its rough topography, is best adapted to forestry, and, in farored localities, to peaches and winter apples. In local areas corn and wheat may be produced. The loam has long been recognized as one of the most valuable soils for general farming in the Eastern States. It is a natural bluegrass soil, and therefore makes the finest of pastures, while clover and timothy do almost equally as well for hay. It is admirably adapted to corn and well adapted to wheat and apples. The York Imperial, Winesap, Smokehouse, and Ben Daris varieties of apples do particularly well. The sandy loam in the lower lying areas and valleys is well

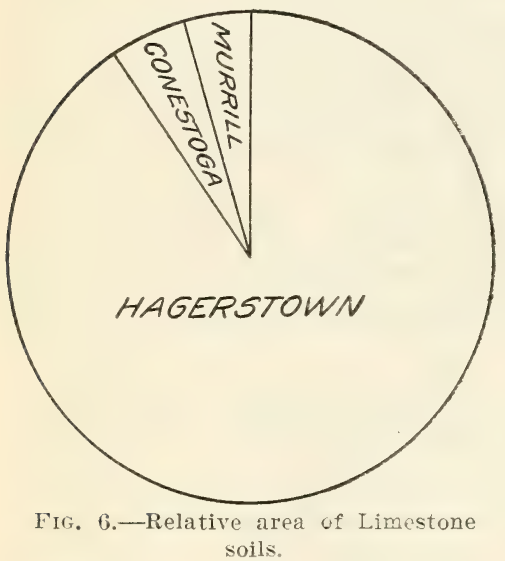
adapted to corn, grass, and clover, and locally to wheat. The ridges and slopes are suited to peaches and apples, and several large orchards have proved successful financially. Medium to late truck and canning crops give fair returns. The clay is a strong soil and well adapted to clover, grasses, wheat, and corn. Clover and timothy mixed give large yields of hay. Bluegrass is the natural pasturage. The soil is heavy and requires the heariest farm equipment. It is adapted to intensive dairying, where the cows are confined and a minimum of pasturing practiced. The silt loam is an excellent heavy general farming soil, being well adapted to corn, wheat, and hay, and also to late fruits and regetables. The clay loam is practically similar in crop adaptation and yields to the Hagerstown clay. It occupies a very small area.

Conestoga series.-The soils of this series are yellowish brown to brown, with yellow and gray mottled subsoils, having a greasy feel and often showing a reddish cast. They are derived from calcareous shale modified by associated thin sandstone and shaly limestone and often contain enough finely dirided mica to impart a greasy feel to the subsoil. Shaly limestone. fragments of the parent rock, are of common occurrence in the subsoil and throughout the soil section. The soils are not quite so productive as the corresponding members of the associated Hagerstown series, but are suited to the production of general farm crops, such as wheat, oats, corn, clover, and grass. 
The clay, the only type so far encountered in Virginia, is not quite as desirable a soil as the Hagerstown clay. It is best adapted to wheat and grass, producing wheat of a superior quality. Large yields of timothy and clover are secured. The soil naturally runs to bluegrass and much of the area is well suited to pasturage.

Murrill series.-The soils of the Murrill series are brown, with yellowish-brown to reddish subsoils. They occupy undulating to gently sloping areas near the foot of mountains and ridges and are derived from limestone, shale, and sandstone material. The subsoils usually consist of residual material from limestone modified somewhat by shale in certain areas. The surface soils consist principally of colluvial material from the adjoining slopes and are composed chiefly of sandstone and shale, though some limestone enters into this colluvial wash. The members are less productive than the well-drained associated limestone soils, but are well suited to corn, wheat, oats, grass, and clover. The sandy members produce good yields of vegetables.

The clay loam, the only type so far mapped in Virginia, is well adapted to wheat, corn, grass, dark manufacturing tobacco, and apples. Large yields of tobacco are secured, the chief use of which is for black plug wrapper or export cigar wrapper, and which sells at a higher price than tobacco grown on other soils in its locality.

Decatur series.-The soils and subsoils are characteristically of a reddish-brown to deep-red color and are derived mainly from pure limestone, although some areas show traces of chert. These soils are developed as nearly level to gently rolling valley lands and are admirably adapted to corn, small grains, and forage crops. Under proper climatic conditions cotton can also be grown. The clay loam, the only type so far encountered in the State, occurs in a very small area.

\section{DESCRIPTION AND USE OF THE SOILS OF THE RIVER FLOOD PLAINS PROVINCE.}

Wickham series.-The surface soils are reddish or reddish brown and contain a higher percentage of organic matter than the Norfolk series. They usually overlie reddish, micaceous heavy sandy loam or loam subsoils, which become coarser, looser, and more incoherent at about 30 inches. These soils occupy river terraces in the higher part of the Coastal Plain near the Piedmont Plateau boundary. They generally have a level or gently undulating surface, are fairly well drained, and have a relatively high agricultural value.

The loam is well adapted to corn, wheat, oats, and timothy. It is considered more desirable for wheat and oats than the Congaree loam, but, in some localities, not so good for corn. The sandy loam is a fair soil for corn and oats and well adapted to potatoes, truck crops, and 
light farming. The sand is essentially an early truck soil. It is especially adapted to matermelons, beans, and rye, but is too light for the profitable production of heart farm crops. The clay loam has the smallest representation of any of the Wickham soils, but is the strongest soil of the series and is especially suited to corn, grasses, wheat, and oats.

Congaree series.-The soils and subsoils of the Congaree series are brown to reddish brown. there being comparatirely little change in texture, structure, and color from the surface downward. Occasionally grarish and yellowish mottling is encountered in the subsoil of the poorly drained areas. These soils are developed in the orerflowed first bottoms of the streams of the Piedmont region and in similar positions in the Coastal Plains along streams issuing from the Piedmont. The material is derired from the soils of the Piedmont region, with some admixture of Appalachian material. and in the

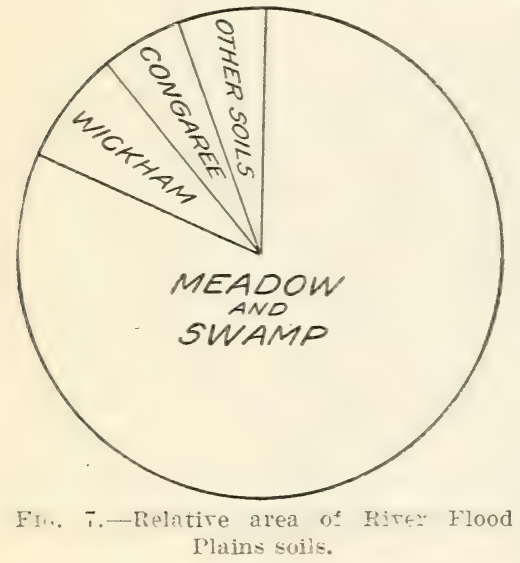
Coastal Plains a slight mingling of Coastal Plains material. The soils are very productive, but are usually poorly drained, and crops are sometimes damaged by overflows. Extensive areas are under cultivation to corn, oats, and forage crops; in the southern part of the State to cotton, and still farther south to sugar cane.

The loam is well adapted to corn and grasses, and, where drainage is adequate, to wheat and oats. It produces an excellent natural pasturage for summer grazing of cattle, and large yields of rorn are secured without fertilizer. The fine sandy loam usually lies at slightly higher elerations than the Congaree loam. It is adapted to corn, oats, and watermelons.

Cumberland series.-The surface soils are bromn to rellowish brown in color. while the subsoils are yellow to reddish yellow. The series comprises high terrace soils in the Limestone region of the South. Many of the larger streams trarersing the Limestone region formerly flotred at considerably higher lerels. and this resulted in the formation of more or less distinct erosion terraces. Upon these terraces was deposited a thin stratum of allurial material. The surface soils of this series are therefore partly alluvial, while the subsoils are residual from the underlying limestones.

The gravelly loam is of limited extent. It is used to some extent for corn, oats. and grasses. The loam also has a small acreage. 
It is used mainly for corn and wheat and to some extent for fruits. The clay loam is adapted to the production of corn and pasture grasses.

Huntington series.-The Huntington soils are light brown to brown and the subsoils yellow to light brown. In many cases there is little change in the color or character of the material from the surface downward. The soils are developed in the Limestone and Appalachian Mountain regions in the first bottoms of streams, where they are subject to overflow. They consist of material derived from limestone, sandstone, and shale soils. They represent the bestdrained soils of the first bottoms of the region, and are admirably adapted to corn, oats, grass, forage crops, and, under proper climatic conditions, to cotton.

The loam, when well drained and lying above high water, is well suited to corn, tomatoes, and other canning crops. The silt loam occupies a very small acreage. It is well adapted to corn, potatoes, and hay. Sorghum does well in some localities.

Toxaway series.-The Toxaway soils are light brown to dark brown. The subsoils are yellowish brown to dark brown. This series occupies the first bottoms of streams in the southern Appalachian Mountains and consists of material derived from the soils of this region, principally from granitic, gneissic, and schistose rocks. They are largely subject to overflow. Along the outer margins there is more or less influence from colluvial material from adjoining slopes. The soils are especially adapted to corn, grass, oats, rye, cabbage, pumpkins, cucumbers, potatoes, and other vegetables. The fine sandy loam, the only type so far mapped in the State, is of very small extent.

Altavista series.-The surface soils are gray, the subsoils yellow, mottled yellow and gray, or mottied yellow, gray, and red. The series is developed as well-defined to rather indistinct terraces along streams and lies above normal overflow. The soils are encountered in the Piedmont region and in the near-by Coastal Plains along. streams issuing from the Piedmont. Typically the material is alluvial in origin, but in places near foot slopes some colluvial material has modified the alluvial deposits. In places also the subsoil appears to be at least partly residual in origin. The flatter areas need surface drainage. Tobacco, corn, wheat, oats, and grass do well.

The fine sandy loam, the only type of this series which has been found in Virginia, is of very small extent. Upon the better-drained areas good yields of corn and hay are secured, and in some localities melons and vegetables are successfully produced.

Holston series.-The Holston series consists of yellowish-brown to brown surface soils and yellow subsoils. It is developed on old allu- 
vial terraces, sometimes standing 200 feet or more above the first bottoms of present streams. The soils consist principally of material washed from sandstone and shale soils, and on this account are somewhat less productive than the Elk soils, which they closely resemble, but which contain more limestone material. The Holston soils are generally underlain by sandstone or shale, and in places the lower subsoil seems to be partly residual from these rocks. The soils give fair to good yields of corn, wheat, oats, grass, clover, and forage crops. The silt loam is the only type so far encountered in the State, and this to a very small extent.

Meadow and Swamp constitute by far the larger part of the River Flood Plains which has been mapped so far in the State. Both are classed under miscellaneous material, as the material is too immature to classify with the soils. The meadow is subject to frequent overflow and is liable to change its character with the extent, volume, and velocity of the overflow. It, therefore, has not acquired a definite and persistent texture, which is one of the requisites of classified soil types. Furthermore, drainage is usually not yet well established and the material lacks that circulation of water and of air which is generally associated with classified soils. The Meadow is usually adapted to certain grasses, which often give valuable pasturage or hay crops. The reclamation of many meadow areas may easily be accomplished by drainage, but in the case of others it may be necessary to protect them from overflow.

The Swamp is still more immature than the Meadow, in that it rarely has any circulation of water or air, as do agricultural lands, but is under water much or all of the time and is unfit, in its natural condition, for farm crops. However, this may also be reclaimed and converted usually into very productive material, so that Meadow and Swamp may be considered valuable undeveloped resources of the State.

Table showing the extent and location of each soil type encountered in the survey.

\begin{tabular}{|c|c|c|c|}
\hline Province and soil type. & $\begin{array}{l}\text { Key number } \\
\text { to report. }\end{array}$ & $\begin{array}{l}\text { Area of } \\
\text { type. }\end{array}$ & $\begin{array}{l}\text { Area of } \\
\text { series. }\end{array}$ \\
\hline 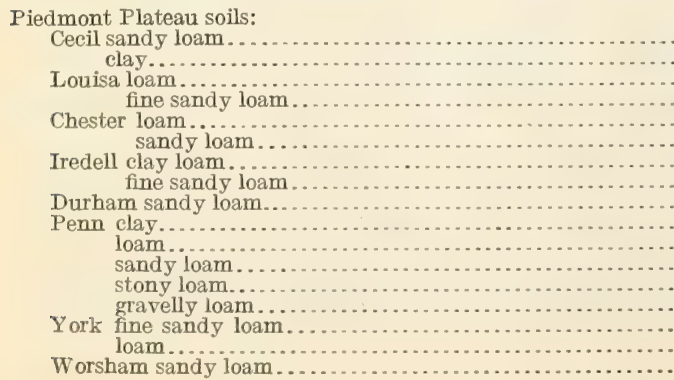 & $\begin{array}{r}1,2,3,6,8,11 \\
1,2,346,7,8,11 \\
4,8 \\
4,8 \\
1,7 \\
7 \\
2,4,7,8,11 \\
4 \\
2,6,8,11 \\
1,7 \\
4,7 \\
1,4 \\
7 \\
7 \\
4 \\
2,4 \\
11\end{array}$ & $\begin{array}{r}\text { Acres. } \\
590,282 \\
354,992 \\
256,704 \\
147,392 \\
171,328 \\
27,200 \\
142,430 \\
3,840 \\
59,558 \\
25,664 \\
23,232 \\
6,976 \\
1,280 \\
512 \\
14,464 \\
4,032 \\
8,520\end{array}$ & $\begin{array}{l}\text { Acres. } \\
\begin{array}{r}945,274 \\
404,096 \\
198,528 \\
146,270 \\
59,558\end{array}\end{array}$ \\
\hline
\end{tabular}


Table showing the extent and location of each soil type, etc.-Continued.

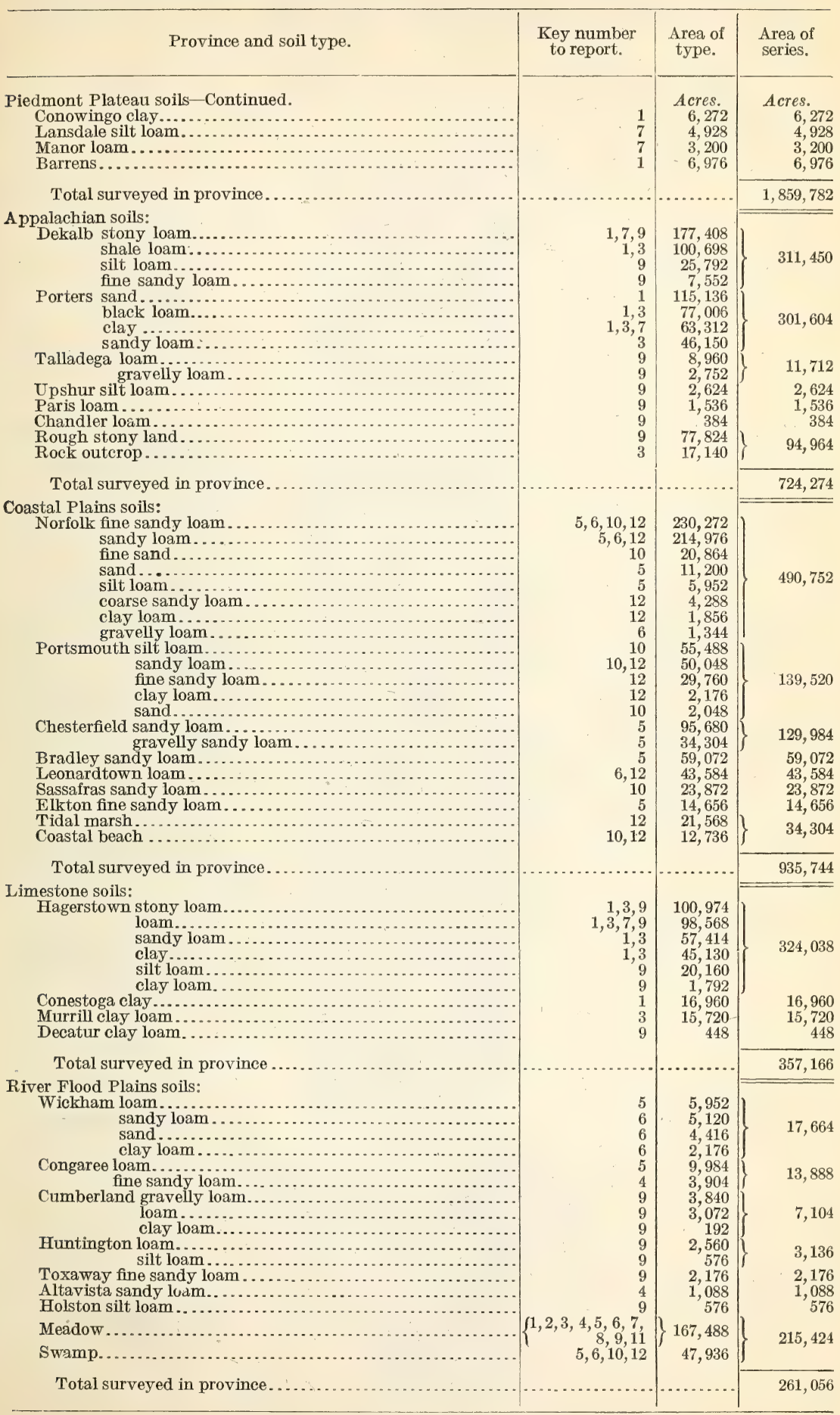


Reference list and key to the numbers given in second column of the foregoing table, showing the areas surveyed, the soils mapped in each area, and the changes made in classification since the publication of the reports.

Name of area.

1. Albemarle area, 1902

2. Appomattox County, 1904

3. Bedford area, 1901.

4. Campbell County, 1909.

5. Chesterfield County, 1906.

6. Hanover County, 1905

7. Leesburg area, 1903

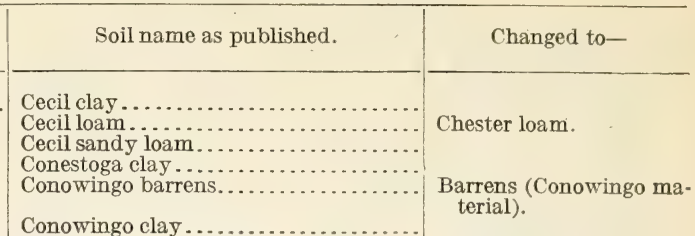

Conowingo clay

Edgemont stony loam .............

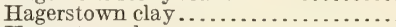

Hagerstown loam.

Hagerstown sandy loam...............

Hagerstown shale loam.............

Hagerstown stony loam . . . . . . . . . . .

Meadow.

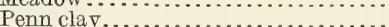

Penn sandy loam . . . . . . . . . . . . . .

Porters black loam .....................

Porters clay ..................................

Porters sand ..........................

Cecil clay ..........................

Cecil loam.......................

Cecil sand..............................

Cecil sandy loam....................

Tredell clay loam . ..................

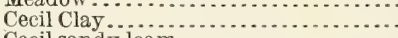

Cecil sandy loam.

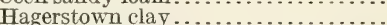

Hagerstown loam ....................

Hagerstown shale loam ...............

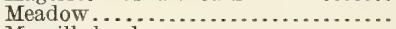

Murrill clay loam.......................

Murrill sandy loam................

Murrill stony loam .......................

Porters black loam.....................

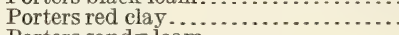

Porters sandy loam ..................

Rock outerop.......................

Alt́avista fine sandy loam ............... Cecil clay .......................... Congaree fine sandy loam ............

Iredell clay loam ....................

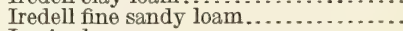
Louisa loam

Louisa fine sandy loam

Meadow (Congaree material) .........

Penn loam ...........................

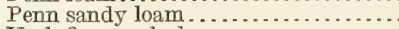

York fine sandy loam ...............

York loam .

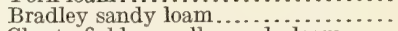

Chesterfield gravelly sandy loam......

Chesterineld sandy loam................

Congaree loam ......................

Elkton fine sandy loam ...............

Meadow .............................

Norfolk fine sandy loam...............

Norfolk sand

Norfolk sandy loam ....................

Norfolk silt loam . ...................

Swamp.

Wickham loam

Cecil clay .......................

Cecil sand............................

Cecil sandy loam ....................

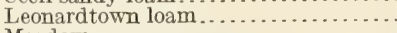

Meadow

Norfolk fine sandy loam .............

Norfolk gravelly loam.

Norfolk sandy loam.

Swamp...

Wickham clay loam ................

Wickham sand ...................

Wickham sandy loam ...................

Cecil clay ..........................

Cecil loam .........................

Cecil mica loam ....................

Dekalb stony loam ....................

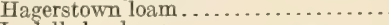

Iredell clay loam ...................

\section{Dekalb ston y loam.}

Dekalb snale loam.

York loam.

Durham sandy loam.

Dekalb shale loam.

Hagerstown sandy loam. Hagerstown stony loam.

Porters clay.

Durham sandy loam.

Chester loam

Manor loam.

Lansdale silt loam. 
Reference list and key to the numbers given in second column of the foregoing table, showing the areas surveyed, the soils mapped in each area, and the changes made in classification since the publication of the reports-Continued.

7. Leesburg area, 1903 (continued)....

9. Montgomery County, 1907.

10. Norfolk area, 1903

11. Prince Edward area, 1901.

12. Yorktown area, 1905 .

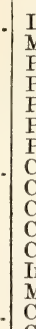

Norfolk sandy loam....................

Portsm

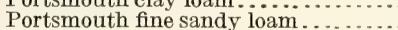

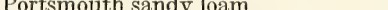

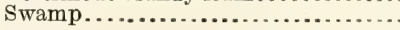

Louisa fine sandy loam.

Louisa loam.

Durham sandy loam.

Chandler loam.

Talladega gravelly loam. Talladega loam.

Cumberland loam.

Coastal beach

Portsmouth silt loam. Do.

Sasafras sandy loam.

Norfolk fine sand.

\section{Tidal marsh.}

Coastal beach

ADITIONAL COPIES of this publication $A$ may be procured from the SUPERINTENDENT OF Documents, Government Printing Office, Washington, D. C., at 5 cents per copy

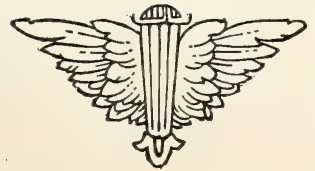






